\title{
Para além de uma crítica aos direitos humanos: a interculturalidade como alternativa
}

\section{Beyond a human rights critique: interculturality as an alternative}

\author{
Michelle Alves Monteiro \\ Tatiana Cardoso Squeff
}

\begin{abstract}
Resumo
A fim de se trazer à tona a problemática que o sistema jurídico gera, baseado numa estrutura colonialista, europeia e universalista, que prima pela observância de direitos humanos, cujo discurso é fundamentalmente excludente àqueles que não fazem parte do grupo dominante - o homem branco europeu proprietário cristão ocidental, o presente trabalho tem como finalidade apresentar as incompletudes e desigualdades reproduzidas pelo discurso dos direitos humanos. Assim, para que se vislumbrem os paradoxos existentes, apresenta-se um breve estudo acerca da construção da concepção de direitos humanos, dando-se destaque aos direitos naturais, que serviram de suporte para o que se ainda entende por direitos humanos, de modo que se elabora uma crítica a tal discurso exatamente por ele ser eurocêntrico, universalista, colonialista e, portanto, restrito, a fim de que seja possível ressaltar outra forma de pensar os direitos humanos, reconhecendo e respeitando a diversidade cultural, tendo por escopo a formação de um discurso dos direitos humanos emancipatório e não excludente, que prime pela interculturalidade.
\end{abstract}

Palavras Chaves: Direitos Humanos. Universalismo. Teoria Crítica. Interculturalidade.

\begin{abstract}
In order to bring to light the problematic that the legal system generates, based on a colonialist, European and universalist structure, which emphasizes the observance of human rights, whose discourse is fundamentally excluding to those who are not part of the dominant group - the white European Christian Western landowner man, the present article aims to present the incompleteness and inequalities reproduced by the discourse of human rights. Hence, in order to check the existing paradoxes, a brief study on the construction of the concept of human rights is presented, parting from the natural rights, which served as support for what is still understood by human rights. Thus, a critique of such discourse is made precisely because it is Eurocentric, universalist, colonialist and, therefore, restricted, so that it is possible
\end{abstract}


to analyze a way of rethinking human rights, recognizing and respecting cultural diversity, with the aim of forming an emancipatory and non-exclusionary human rights discourse that emphasizes interculturality.

Keywords: Human Rights. Universalism. Critical Theory. Interculturality.

\section{Introdução}

Ao longo da história da humanidade, buscou-se proteger a pessoa humana frente às violências cometidas pelo Estado, de forma que, somente após as barbáries incorridas por um Estado nazista, uniformizador e racista, a comunidade internacional preocupou-se, ao editar a Declaração Universal dos Direitos Humanos, em 1948, em estabelecer e positivar direitos, tidos como humanos, os quais todos deveriam respeitar e observar. Ocorre que, para além de toda a incoerência constante nesse discurso, tendo em vista que, por exemplo, a Europa mantinha suas colônias na África e na Ásia, mediante um sistema de exploração e subalternidade do "outro", ao se determinar certos direitos, baseados em uma racionalidade excludente, em um individualismo alimentado pelo capitalismo competitivo e em uma cultura única, a ocidental, particularidades são postas de lado, gerando uma situação de silenciamento do diferente e superioridade de um grupo dominante.

Destarte, a fim de que se possa repensar as estruturas e buscar um sistema mais plural e menos reprodutor de desigualdades, abordar-se-á a construção do discurso dos direitos humanos, trazendo uma breve análise histórica e filosófica, para que se entenda o porquê da defensa por direitos humanos universais; partindo, para tanto, desde as duas principais revoluçōes burguesas, as quais deram o impulso para se garantir a lógica eurocêntrica capitalista e universalista dos direitos humanos, até a Declaração Universal dos Direitos Humanos, marco primordial para a concretização e efetivação dos direitos do homem históricos. Após, desenvolver-se-á uma crítica a esse discurso, erguido em uma única realidade, a europeia, entendendo como humano o homem branco de classe média ocidental e impondo uma homogeneidade inexistente frente a uma comunidade internacional pluriétnica e multicultural.

Por fim, como opção mais democrática, emancipatória e de resistência, apresentar-se-á a concepção intercultural dos direitos humanos, despindo-se do caráter eurocêntrico, universal, colonizador, branco e excludente do sistema.

\section{A construção histórica dos direitos humanos}

A sociedade percorreu inúmeras fases no decorrer da história da humanidade, de sorte que, juntamente com ela, os direitos foram evoluindo lenta e conjuntamente (BOBBIO, 2004, p. 209), sendo substancial, para que se analise a problemática trazida, um esboço histórico das principais situaçōes e momentos que levaram a comunidade (internacional) buscar definir determinados direitos que fossem primordiais para a proteção como um todo e com sua necessária positivação em âmbito interno.

Nesse contexto, Bobbio (2004, p. 31) aponta que "os direitos do homem são direitos históricos, que emergem gradualmente das lutas que o homem trava por sua própria emancipação e das trans-

\footnotetext{
${ }^{1}$ Aqui, utiliza-se a expressāo "outro" no sentido desenvolvido por Edward Said (1995), o qual entendia que, por causa do imperialismo, os sujeitos são construçōes daqueles que detém certa identidade homogênea e dita como superior, a partir de um processo de subordinaçāo, de generalização, de inferiorizaçăo, de silenciamento, de exclusāo, com representaçōes baseadas em estereótipos e preconceitos, por meio de práticas concebidas, primeiramente, pelos europeus, fundadas no uso do poder e do discurso hegemônico e civilizatório.
} 
formaçōes das condiçōes de vida que essas lutas produzem". Admite-se, portanto, que os direitos do homem foram concebidos com o surgimento deste, angariando força no decurso do tempo, porquanto seu objetivo visa à proteção, de maneira universal, da pessoa humana, bem como se fundamenta na luta contra os tipos de opressão e o anseio de trazer o bem-estar para o sujeito inserido na sociedade (RAMOS, 2016, p. 33).

Desde a Antiguidade, já se vinha ensaiando conceitos que seriam utilizados até os dias de hoje, bem como estruturas jurídicas de reconhecimento de direitos dos indivíduos. Ocorre que, em virtude da simplicidade e da brevidade de um artigo acadêmico, uma análise mais minuciosa da construção histórica do que se entende por direitos humanos restaria prejudicada, vez que superficial. Por essa razão, parte-se da concepção de jusnaturalismo/direitos naturais, trazidos no período moderno europeu.

O que se entende por direitos naturais está fundado no sentido de que os homens enquanto tais têm direitos que, por natureza, ninguém, muito menos o Estado, pode lhes subtrair. A influência é tanta que as primeiras palavras apresentadas na Declaração Universal dos Direitos Humanos vão no sentido defendido pelos jusnaturalistas: "[t] odos os homens nascem livres e iguais em dignidade e direitos", sendo apenas um modo diferenciado de se entender que os homens são livres e iguais por natureza (BOBBIO, 2004, p. 28).

E são esses argumentos que foram base para o pensamento iluminista eclodido nas declaraçōes que viriam a surgir posteriormente, permitindo que se construísse um Estado e um direito que tivessem por base uma concepção individualista, porquanto o novo homem moderno, nascido da desestruturação da sociedade e tradiçōes medievais, elimina Deus do foco das instituiçōes (BRAGATO, 2009, p. 67), reconstruindo sua constituição usando, ao invés da autoridade divina, somente a razão.

Sendo assim, tem-se que a doutrina dos direitos do homem surgiu a partir da ótica jusnaturalista, que tinha como escopo a alegação de existirem determinados direitos que, independentemente do Estado, pertencem ao ser humano enquanto detentor dessa natureza, ou seja, em seu estado de natureza, o homem detém certo direitos, inalienáveis, como o direito à vida, à propriedade, à liberdade, de maneira que se passa a questionar os dogmas da Igreja e o caráter autoritário do Estado, culminando nas primeiras declaraçōes (BOBBIO, 2004, p. 68-9).

É verdade que a ideia da universalidade da natureza humana é antiga, apesar de ter surgido na história do Ocidente com o cristianismo. Mas a transformação dessa ideia filosófica da universalidade da natureza humana em instituição política (e nesse sentido podemos falar de "inova(ção"), ou seja, em um modo diferente e de certa maneira revolucionário de regular as relaçōes entre governantes e governados, acontece somente na Idade Moderna através do jusnaturalismo, e encontra a sua primeira expressão politicamente relevante nas declaraçōes de direitos do fim do século XVIII. (BOBBIO, 2004, p. 204)

As revoluçōes liberais, primeiro com a inglesa, depois com a americana e a francesa, assim como suas declaraçōes de direitos, assinalaram a primeira evidente afirmação dos direitos humanos, pretendendo a universalidade, já que todos os homens, por causa de sua natureza humana, são dotados de direitos intrínsecos a sua condição.

A revolução americana, na qual se deu o processo de independência das treze colônias britânicas com o desenvolvimento da primeira Constituição do mundo, e é considerada o ato inaugural da democracia moderna (BRAGATO, 2009, p. 79), teve como base a insurgência da burguesia coIonial frente aos impostos onerosos cobrados pela metrópole e dos bloqueios comerciais que ela impusera; gerando, portanto, o anseio pela emancipação.

Por essa razão, em 4 de julho de 1776, editaram a Declaração de Independência dos Estados Unidos, definindo que "todos os homens são 
criados iguais, sendo-lhes conferidos pelo seu Criador certos direitos inalienáveis, entre os quais se contam a Vida, a Liberdade e a busca pela Felicidade", de maneira que "para garantir estes direitos, são instituídos Governos entre os Homens, derivando os seus justos poderes do consentimento dos governados"; estipulando, portanto, o direito político de autodeterminação dos homens, sendo geridos a partir de sua liberdade de escolha. Donnelly (2013, p. 88-9) assevera que a reivindicação americana arraigou-se nāo em direitos tradicionais e privilégios de poucos, mas sim na humanidade do homem, dada pelas leis da natureza e por Deus.

Desta feita, a revolução americana serviu de exemplo e estímulo para as revoluçōes no continente europeu, tendo em vista que "idêntico eram os princípios inspiradores, bem como seu fundamento, o direito natural; idêntico era o desfecho, o governo fundado no contrato social, a república como governo que rechaça para sempre a lei da hereditariedade, a democracia como governo de todos" (BOBBIO, 2004, p. 82).

Treze anos após o primeiro registro de nascimento dos direitos humanos na história, a revolução francesa não só reafirma a defesa da liberdade e da igualdade dos homens, como também a reforça. O Estado anterior à revolução, que ensejou na luta do povo contra o governo, já não era mais eficiente e capaz de organizar a economia de acordo com os interesses da burguesia local, além do fato de que tanto as elites religiosas, quanto a nobreza não queriam abrir mão de seus privilégios, se negando a alterar o status quo capitaneada pela monarquia; resultando, por conseguinte, na insatisfação popular que buscou por uma ruptura com esse modelo.

É, nesse cenário, que a Assembleia Nacional Constituinte, em 27 de agosto de 1789, constituiu a Declaração Francesa dos Direitos do Homem e do Cidadão, consagrando como direitos inatos a todos os seres humanos a igualdade e a liberdade, de modo que se aboliram os privilégios, direitos feudais e imunidades de castas, principalmente a aristocracia de terras, usando por lema "liberdade, igualdade e fraternidade" (RAMOS, 2016, p. 45) e concretizando a influência jusnaturalista ao mencionar, para além de "todos os homens nascem livres e com direitos iguais", que os direitos naturais são "inalienáveis e sagrados" ao homem.

Portanto, muito embora desde a Antiguidade esboçou-se a noção do ser humano como sujeito de direitos e não só deveres, foi com a Declaração feita na revolução francesa que se trouxe o reconhecimento do homem, no caso do cidadão, como sujeito de direito, por meio do nascimento do Estado de direito, vez que, como Bobbio (2004, p. 58) aponta, no Estado governado por um déspota, os indivíduos não possuem direitos, mas apenas deveres; no Estado absolutista, aos indivíduos, em relação ao soberano, são garantidos direitos privados, mas quando do Estado de direito, o indivíduo detém, frente ao Estado, além de direitos privados, direitos públicos, de maneira que o Estado de direito se faz de Estado dos cidadãos.

Em comparação, ao passo que a revolução americana buscou muito mais restaurar os tradicionais direitos de cidadania em face dos abusos do poder monárquico da metrópole, a revolução francesa deu-se no sentido de mudar completamente as condiçōes de vida em sociedade, isto é, nas palavras de Comparato (2004, p. 51), "apagar completamente o passado e recomeçar a História do marco zero". À vista disso, enquanto os norte-americanos tinham a pretensão de conquistar sua independência em relação à Coroa britânica, os franceses possuíam o intento de liberar os povos da opressão do Estado, razão pela qual seus princípios ecoam até os dias de hoje, tendo a Declaração de 1789 tida como a primeira de vocação universal.

É, dessa forma, que, para além de os direitos do homem surgirem e se afirmarem como direitos inerentes à condição humana em face aos abusos 
do poder do Estado, representavam, para a doutrina liberal, com o reconhecimento das liberdades individuais, a "emancipação do poder econômico dos indivíduos do jugo e do arbítrio do poder político" (LAFER, 2011, p. 126); sustentando, consequentemente, as bases do liberalismo clássico, dando origem ao Estado Liberal. Salienta-se aqui também que, em verdade, se tem, por meio da Declaração francesa de 1789, a adoção da burguesia no poder do Estado como classe dominante.

Ainda, ressalta-se que os direitos trazidos pelas duas principais revoluçōes do século XVIII, ou seja, a consagração dos direitos naturais, determinando que os homens são iguais e livres, dizem respeito aos direitos do homem e não da muIher, sendo que a figura masculina em questão é quase que exclusivamente branca; causando, portanto um cenário de opressão e exclusão de alguns grupos minoritários, como a manutenção da escravidão dos negros nos EUA e do poder sobre as colônias africanas na França, bem como a negação ao reconhecimento de direitos às mulheres francesas (BRAGATO, 2009, p. 80), motivos que levaram Douzinas (2009, p. 121) a expor que esse período foi conhecido como a era do Estado e da construção de impérios, época do surgimento do nacionalismo, do racismo e do sexismo, elementos que se vislumbraram serem da cultura europeia.

Destarte, a sociedade liberal, ao garantir, apenas nos documentos, a liberdade com base na igualdade de todos perante a lei, criou-se um crescente problema na desproteção dos trabalhadores, os quais são acuados, por meio do novo sistema instaurado pós-revolução, a se empregarem em empresas capitalistas, de modo que patrōes e operários eram, de acordo com o disposto em lei, contratantes em perfeito pé de igualdade ${ }^{2}$, com liberdade para decidir sobre salários, carga horária e outras condiçōes de trabalho. Ocorre que, como se sabe, a relação empregador-empregado é uma relação, para além de exploração e poder, de hipossuficiência do mais fraco, o qual é aquele que não detém os meios de produção, ou seja, o proletário e é, por conta disso, que surgem os movimentos socialistas na busca de assegurar condiçōes materiais mínimas de sobrevivência, usando o ataque ao modo de produção capitalista como principal argumento (RAMOS, 2016, p. 47).

Por conseguinte, o reconhecimento de direitos humanos de caráter econômico foi fundamental para que se entendesse como titular de direitos não mais o ser humano abstrato, como pretendia o capitalismo, mas sim um agrupado social de indivíduos abatidos pela miséria, fome, marginalização e opressão do capital, protegendo o trabalhador do sistema capitalista de produção, "cuja lógica consiste em atribuir bens de capital um valor muito superior ao das pessoas" (COMPARATO, 2004, p. 53). Tal prestígio deu-se por força de diversos influências e eventos históricos como a Revolução Russa, em 1917, a Constituição do México, em 1917, a Constituição de Weimar, em 1919, e, no Brasil, a Constituição de 1934, além de, no plano internacional, ser criada a OIT (Organização Internacional do Trabalho), voltada às melhorias das condições de vida e de trabalhos dos trabalhadores, criada em 1919, pelo próprio Tratado de Versalhes, o qual pôs um fim à Primeira Guerra Mundial (RAMOS, 2016, p. 48). Inaugura-se, com isso, o esboço de um Estado Social, que conta como plano de fundo as reivindicaçōes das camadas excluídas pela exploração do capital por um direito de participar do "bem estar social".

Tendo em vista a grande extensão que a temática aborda e a necessidade de ser sucinta a pesquisa neste tópico do presente artigo, passa-se agora à explanação da afirmação do discurso dos direitos humanos a partir das consequências da Segunda Guerra Mundial.

\footnotetext{
${ }^{2}$ Douzinas (2009, p. 100) sustenta que, seguindo a lógica marxista, o homem detentor de direitos à liberdade e à igualdade, introduzidos no texto da Declaração de 1789, nada mais é do que o homem branco burguês que se voltava ao mercado e que tinha a propriedade como bem jurídico além de privilegiado, resguardado, de modo que se tratava, concretamente, de um sujeito pré determinado com seu gênero, classe e poder.
} 
Ora, a criação efetiva de um direito internacional dos direitos humanos está intrinsecamente conexa à nova organização mundial no cenário pós-Segunda Guerra, porquanto se tratou de uma reação às atrocidades cometidas pelos nazistas; inserindo, desse modo, a temática dos direitos humanos na Carta da ONU, a qual menciona em diversos momentos a terminologia direitos humanos. Contudo, a Carta não elencou de forma expressa os direitos que deveriam ser ditos como inerentes à condição humana, essenciais para a existência do homem, motivo pelo qual, em 1948, sob a forma de Resolução da Assembleia Geral da ONU, foi aprovada a Declaração Universal de Direitos Humanos, a qual, esta sim, dispōe, nos seus 30 artigos, um rol de direitos humanos aceitos internacionalmente.

No momento em que os seres humanos se tornaram supérfluos e descartáveis, no momento em que vige a lógica da destruição, em que cruelmente se abole o valor da pessoa humana, torna-se necessária a reconstrução dos direitos humanos, como paradigma ético capaz de restaurar a lógica do razoável. A barbárie do totalitarismo significou a ruptura do paradigma dos direitos humanos, por meio da negação do valor da pessoa humana como valor fonte do direito. Diante dessa ruptura, emerge a necessidade de se construir os direitos humanos. (PIOVESAN, 2010, p. 122)

Assim, com a valorização da dignidade humana ${ }^{3}$ como suprema, visto ser o Estado um de seus principais violadores, a comunidade internacional viu-se na obrigação de reconstruir os direitos humanos como referencial ético e moral de modo a não se restringir ao âmbito interno do Estado, mas sim legitimá-lo como interesse internacional (PIOVESAN, 2010, p. 122).
A Declaração Universal dos Direitos Humanos, conforme assinala Bobbio (2009, p. 26), ao ser tida como válida por consenso geral ${ }^{4}$, representou a demonstração de que um sistema de valores e princípios fundamentais da conduta humana pôde ser concebido livremente e de forma expressa "pela maioria dos homens que vive na Terra" e, portanto, universal, enunciando uma ideia de comunidade internacional não só formada por Estados, mas também por indivíduos projetados como livres e iguais.

Isto posto, tem-se que a Declaração de 1948 é a afirmação de que os direitos são, concomitantemente, universais e positivos; universais por dizerem respeito ao fato de que os destinatários dos princípios abarcados por ela não são somente os de um determinado Estado, mas sim todos os homens existentes; positivos no sentido de que os direitos não são mais apenas proclamados ou idealmente reconhecidos, pelo contrário, são efetivamente assegurados, de forma escrita, inclusive contra o próprio Estado, caso este os tenha transgredido, de maneira que a universalidade abstrata de direitos naturais acaba por se transformar na particularidade concreta dos direitos positivos a fim de que, ao final, a universalidade abstrata se converta em direitos positivos universais.

Bobbio (2004, p. 33) defende que a "a Declaração Universal representa a consciência histórica que a humanidade tem dos próprios valores fundamentais na segunda metade do século XX. É a síntese do passado e uma inspiração para o futuro".

Por fim, para além de o contexto social, econômico e político ser diferente do da época em que foram estipulados, os direitos humanos, desde a

\footnotetext{
${ }^{3}$ Cabe um adendo quando se trata da questāo da dignidade humana, devendo-se fazer uma importante referência ao principal filósofo e formador do pensamento até hoje utilizado: Immanuel Kant. Ressaltando-se que, por nāo ser foco deste trabalho, apenas mencionar-se-á que, por meio de seus pensamentos, é que se reconheceu que nāo se pode conferir um valor ao homem, porquanto este deve ser analisado como "um fim em si mesmo", já que, para Kant, a dignidade da pessoa humana é um valor inerente aos indivíduos, na qualidade de entes morais, enquanto desempenham, de maneira autônoma, a sua razão, exigindo-se como requisito a liberdade (BIELEFELDT, 2000, p. 68-70). Em síntese, Kant sustenta que a dignidade da pessoa humana se refere à autonomia do ser humano, enquanto ente moral, para a elaboraçāo, por meio da razāo prática, de leis universais, sendo um fim em si mesmo e nunca como um instrumento.

${ }^{4}$ À época da adoção da Declaraçāo, votaram 48 países a favor, sem nenhuma oposição e com 8 abstençōes (da África do Sul, URSS, Bielorrússia, TchecosIováquia, Polônia, Ucrânia, lugoslávia e Arábia Saudita). Ressaltando-se que, muito embora a maior parte da África e da Ásia e algumas partes da América ainda estivessem sob o sistema opressor colonial, a Declaração foi tida como aprovada e aplicada globalmente (DONNELLY, 2013, p. 26).
} 
sua concepção inicial, com um pequeno ensaio já na Antiguidade grega, que contribuiu para a construção racional e universal do discurso, tendo em vista que os direitos humanos são baseados em uma realidade única, qual seja, a europeia, tendo a humanidade digna à figura do homem branco, numa perspectiva que mantém a exclusão das minorias, como as não ocidentais, e que se sustenta num sistema de exploração do capital, é necessário que se faça, para que se tenha um releitura que abarque e reconheça as particularidades do "outro", uma crítica ao caráter universalista dos direitos humanos.

\section{As incompletudes e exclusões do discurso dos direitos humanos e a interculturalidade como saída}

A construção do discurso dos direitos humanos é histórica, no sentido de que cada época da humanidade contribuiu para os fundamentos expostos na sua positivação, com a Declaração Universal em 19485. Percebe-se que o discurso é produzido por um caráter eurocêntrico, tendo em vista que se deu no âmbito europeu a sua estruturação; ocidental, por causa da cultura dominante; hegemônico e homogêneo, por sustentar a ideia de que toda e qualquer sociedade, independentemente das particularidades que detém, deve respeitar e introduzir ao seu sistema interno a proteção aos direitos humanos. Sendo assim, este tópico se restringe a explanar as críticas que são feitas ao discurso dos direitos humanos, vez que incompleto, excludente e vazio.

Os direitos humanos foram idealizados com alicerces na invisibilidade do "outro". Isso porque o pensamento impulsionador do discurso, que tem como auge o iluminismo das revoluçōes do século VIII, deu suporte a todo o processo de colonização, como bem indica Baldi (2008, p. 305), pri- meiramente com a colonização fundada na escravidão de índios e negros, obscurecido tanto na discussão ibérica (nos países da América Latina), quanto na subsequente anglo-francesa (nos países da África e da Ásia); e, posteriormente, com a Declaração Universal em si, tendo em vista que os países os quais levantaram a bandeira da luta contra as atrocidades cometidas pelo nazismo conservavam colônias na Ásia e na África.

Ainda nessa percepção, quando se trabalha a questão das "geraçōes" de direitos humanos, Baldi (2008, p. 305) refere que, para além do movimento temporal, tal abordagem é espacial, porquanto se se deslocar os direitos humanos com o ponto de origem na Europa e passar para o resto do mundo verificar-se-á que, é na ocasião em que a Europa "concebia" os direitos humanos, os "propulsores da globalização dos direitos humanos estavam nas Américas, lutando contra a opressão colonial europeia", acontecendo também futuramente com os povos africanos e asiáticos, isto é, enquanto se propagava a concepção de direitos humanos pelos europeus, estes detinham poderes coloniais que serviam para explorar, oprimir e criar estereótipos preconceituosos (QUIJANO, 2005) entre os povos das diversas etnias não ocidentais.

A invisibilidade do "outro" dentro da construção do discurso dos direitos humanos se dá também na acepção criada pela modernidade a partir da progressiva expansão da civilização, no sentido de que o mundo não europeu (e norte americano, pela idealização imperialista e globalizada) é percebido como atrasado, arcaico, selvagem.

Por tais razões, ou seja, pelo fato de que o percurso histórico da construção dos direitos humanos é predominantemente único - europeu, questiona-se sobre a viabilidade de os direitos humanos poder representar outros valores e ideias diversos daqueles estabelecidos pelo Ocidente a partir da

\footnotetext{
${ }^{5}$ Necessário se faz, desde já, referir que, conforme Flores (2002, p. 9) sustenta, "falar de direitos humanos, no mundo contemporâneo, supōe enfrentar-se
} desafios completamente diferentes dos que enfrentaram os redatores da Declaração Universal de 1948". 
história contada por este (CASTILHO, 2013, p. 34). E é nesse sentido que se faz necessário estruturar uma crítica ao discurso dos direitos humanos, por se tratar de um conceito europeu criado pelo Ocidente para proteger o homem branco burguês.

Douzinas (2009, p. 176) refere que "o 'homem' dos direitos humanos é literalmente um homem branco de classe média ocidental que, sob as reivindicações de não-discriminação e igualdade abstrata, estampou sua imagem na lei e nos direitos humanos e se tornou a medida de todas as coisas e pessoas". Nota-se, então, que a universalidade dos direitos humanos foi arquitetada, então, pela burguesia a partir de suas necessidades e daquilo que the interessava enquanto classe, tidos como inerentes ao ser humano racional.

Ocorre que tal racionalidade, como visto, não foi concedida a todos, mas sim apenas a uma parcela - a burguesia branca europeia e patriarcal. Por isto, Bragato (2011, p. 110) afirma que o ser pensante se trata, de acordo com a cultura de uma sociedade industrial, apenas de um sujeito hábil a transformar a natureza em dominação, colocando a sua própria racionalidade ${ }^{6}$ como universal e impondo a sua cultura como a mais evoluída e o padrão a ser seguido.

É, em decorrência disso, que, ainda que os direitos naturais abordassem o homem em abstrato, a sua natureza humana, a etnia, o gênero, a classe e a cor configuravam o sujeito dotado de razão e, portanto, de direitos humanos, sendo ele, consoante já mencionado, o europeu, homem, proprietário burguês e branco, na realidade de uma cultura ocidental e liberal?. Sendo assim, o universalismo conferido aos direitos humanos, desde sua origem, para além de salvaguardar apenas uma identidade, é excludente.
A natureza contraintuitiva do universalismo pode levar seu proponente ao extremo individualismo: somente eu mesmo, na qualidade de verdadeiro agente moral ou aliança ética ou representante do universal, posso compreender o que a moralidade requer. Egoísmo moral facilmente conduz à arrogância, e universalismo a imperialismo: se existe uma verdade moral, mas muitos erros, é incumbência de seus agentes impô-la a outros. O que começou como rebelião contra os absurdos do localismo acaba por legitimar a opressão e a dominação (DOUZINAS, 2009, p. 148).

Percebe-se que a pretensão universal dos direitos humanos, ainda que tenha sido construída a partir da irresignação dos indivíduos diante das atrocidades acometidas pelo Estado, carrega um viés impositivo perante aqueles que não fizeram parte do processo, razão pela qual, como consequência, se cria um cenário de superioridade dos que impõem esse universalismo e de subalternização daqueles que são submetidos a ele.

Assim, a fim de que não se permita que haja uma reconstituição de um novo e atual "estado totalitário de natureza", em que se sobrepõe uma etnia sobre a outra, é necessário que se faça uma retomada crítica do pensamento ocidental; pretendendo-se, para tanto, a análise das condiçōes que possibilitem um mundo comum, abarcado pela pluralidade e diversidade.

Desta feita, a crítica que se faz ao discurso dos direitos humanos, para além de seu caráter homogêneo, é no sentido de que ele cria uma hierarquização de dicotomias culturais, ao se colocar a superioridade humana em relação aos não humanos, bem como ao entender que os seres humanos são detentores de direitos apenas pelo simples fato de serem humanos. A incoerência consistente nessa definição do discurso se dá,

\footnotetext{
${ }^{6}$ Cumpre ressaltar que essa imposição da racionalidade europeia como universal foi ostensivamente retratada no âmbito colonial, nas Américas, na África e na Ásia, nas quais os nativos das regiōes eram tidos como irracionais, servindo de argumento para dominaçāo colonial, visto se tratar de um escalonamento de valores aos seres humanos (os dignos aos indignos), conforme Bragato sustenta (2011, p. 108).

${ }^{7}$ Nesse mesmo sentido, "a história dos direitos humanos foi marcada por um placar ideológico e um intenso conflito entre o liberalismo ocidental e outras concepçōes de dignidade humana. Ambos os problemas tornaram-se evidentes a partir do nascimento do código internacional de direitos humanos. As cores ideológicas da Declaração Universal eram evidentemente ocidentais e liberais" (DOUZINAS, 2009, p. 134).
} 
principalmente, por sua intenção de dominação cultural, na medida em que, enquanto a Europa vivia a materialização dos direitos humanos de primeira geração, isto é, dos direitos individuais, para além de seus limites territoriais, promovia uma massiva e sistemática destruição e violação de direitos humanos, por meio do colonialismo (MUZAFFAR, 1999, p. 26).

Constituiu-se, assim, no contexto histórico da cultura moderna ocidental, a categoria de um sujeito racional capaz de direitos, de direitos positivados engendrados por circunstancias valorativas especificas como a emergência do sistema produtivo capitalista, a formação dos Estados-Nacionais, as crescentes demandas políticas de novos segmentos sociais (a burguesia) por liberdade, igualdade e segurança e a defesa pelo direito natural à propriedade privada.

Em verdade, estas famosas e clássicas declaraçōes que projetavam direitos como universais e gerais para todos os homens (os homens são livres e iguais) representavam os interesses e privilégios de segmentos sociais ascendentes economicamente que buscavam instrumentos de proteção ao livre mercado e a garantia de sua propriedade privada. Por detrás dessas enunciações solenes, gerais e humanistas de direitos, ocultavam-se discursivamente conceituaçōes estreitas, abstratas e contraditórias. Tratava-se de direitos idealizados para um homem burguês, racional $e$ individualista. A assertiva de que todos os homens seriam livres e iguais não se aplicava aos sujeitos subalternos das colônias da América Latina, África e Ásia. (WOLKMER, 2015, p. 259)

É, desta maneira, que desponta a visão hegemônica eurocêntrica como propósito não só nacional, mas mundializado que legitimou o genocídio das populaçōes indígenas, o banimento de islâmicos e judeus nos países ibéricos ao fim do século XV, bem como a cruel subjugação dos afrodescendentes à escravidão na América Latina (WOLKMER, 2015, p. 260). Assim, disseminou-se um discurso de criação de direitos determinados por uma cultura ocidental eu- ropeia, marcada por certos atributos e delineada como própria de toda a humanidade, todavia o problema reside no fato de que os valores expressos por tais direitos se revelam como sendo um padrão de vida concebido para o homem ocidental, refutando-se ao outro não europeu, não cristão, não branco esse mesmo padrão estabelecido (WOLKMER, 2015, p. 261).

Os maiores símbolos ocidental liberal do discurso dominante dos direitos humanos são prontamente percebidos, por exemplo, na Declaração Universal de 1948, a qual foi formulada sem a participação da maioria dos povos habitantes do mundo; no reconhecimento praticamente único de direitos individuais, com a exceção do direito coletivo à autodeterminação; que, contudo, foi limitado aos povos subjugados pelo colonialismo europeu; na propriedade conferida aos direitos civis e políticos sobre os direitos sociais e culturais, além do reconhecimento do direito de propriedade como o primeiro direito econômico e, perdurando por muito tempo, como o único (SANTOS, 2010, p. 20).

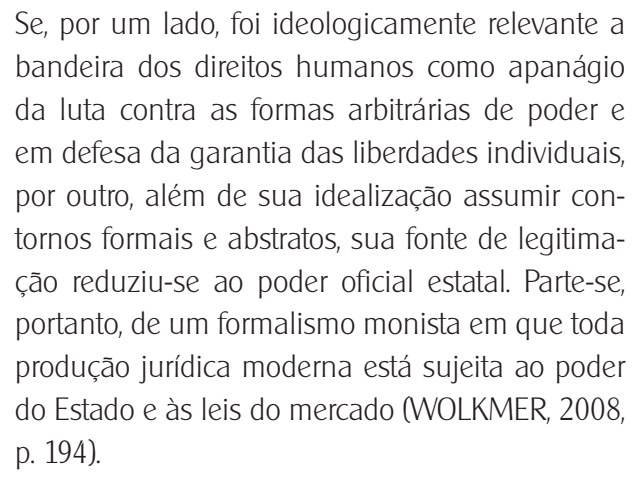

Diante disso, nota-se que os direitos humanos trazem de um discurso indeterminado de legitimação do Estado, ou, ainda, a retórica vaza da rebelião, podendo, em virtude disso, serem usados de planos políticos não como tentativa de humanizar Estados repressivos, mas sim se sobrepor, substituindo por seus próprios regimes também perversos, como aponta Douzinas (2009, p. 129). 
A globalização ${ }^{8}$, cujo estouro se deu no pós-Guerra Fria e que mudou o cenário político, econômico e social do mundo, é produto de todo o processo que fora iniciado desde a colonização das Américas; instaurando, portanto, uma nova forma de poder, baseada na concepção de raça (QUIJANO, 2005, p. 107), tendo em vista que se criou um centro ${ }^{9}$ (a metrópole europeia) e várias periferias mundiais (as regiōes colonizadas e exploradas). Assim, o conceito de raça foi fundamental para que pudesse se elaborar uma hierarquia análoga ao comportamento de dominação e escravização dos nativos colonizados feitos pelos europeus colonizadores (QUIJANO, 2005, p. 107), o que serviria de suporte para o discurso moderno, em que explorava, inferiorizava e desconsiderava o "outro" enquanto não detentor de racionalidade e, por conseguinte, indigno de direitos humanos.

Deste modo, os colonizadores, ao coagir os nativos a viverem e reproduzirem a sua cultura europeia para que pudessem efetivamente dominar os povos, estipularam uma colonização do saber, a qual propiciou a geração como universal de seus valores, trazendo as dicotomias da modernidade, quais sejam, selvagem/civilizado, atrasado/ evoluído, irracional/racional (QUIJANO, 2005, p. 112), as quais são observadas até os dias de hoje, com a questão indígena no Brasil e a questão dos refugiados na Europa ${ }^{10}$, entre outros exemplos.

A colonialidade do poder, portanto, instaura um sistema de dominação, estabelecido por meio da raça, o qual colaborou para as incompletudes e falhas do discurso, de maneira que a função das condutas nas relações sociais, estereótipos e simbologias está relacionada à dependência dessa classificação racial (QUIJANO, 2006, p. 67), a qual serve de instrumento de subjugação e exploração do "outro".

Por sua vez, Santos (2010, p. 13) sustenta que, no momento em que se atribui os direitos humanos como universais, estes tornam-se uma ferramenta para o que sociólogo indica como sendo "choque de civilização", ou seja, os direitos humanos transformam-se em um mecanismo a fim de que o Ocidente imperialista se imponha diante o resto do mundo, operando como um modo de globalização hegemônica.

Isso se deve ao fato de que como é possível, em um mundo pluricultural, multiétnico, pós-colonial, determinar como característica essencial dos direitos humanos o universalismo? Douzinas (2009, p. 221) preconiza que "o individualismo dos princípios universais se esquece de que cada pessoa é um mundo e vem a existir em comum com outras, de que estamos todos em uma comunidade".

Este mecanismo de compreensão histórica influencia na construção de um conhecimento europeu com pretensão de validade universal. O que é europeu é universal, a única filosofia existente é a europeia. As outras formas de compreensão do mundo e da vida são conhecimentos primitivos não complexos ou com menor grau de complexidade, sem sustentação científica. Outras filosofias não existem, sendo admitida, no máximo, por alguns, uma filosofia étnica (uma etnofilosofia)

\footnotetext{
${ }^{8}$ Santos (2010) define globalização como sendo "o processo pelo qual determinada condição ou entidade local estende a sua influência a todo o globo e, ao fazê-lo, desenvolve a capacidade de designar como local outra condição social ou entidade rival".

${ }^{9}$ Para Flores (2002, p. 15), "centro há somente um. O que não coincida com ele é abandonado à marginalidade. Periferias, no entanto, existem muitas. Na realidade, tudo é periferia, se aceitamos que não há nada puro e que tudo está relacionado. Uma visão, a partir da periferia dos fenômenos, indica-nos que devemos abandonar a percepção de "estar no entorno", como se fôssemos algo afastado do que nos rodeia e que deve ser dominado ou reduzido ao centro que inventamos. Não estamos no entorno. 'Somos o entorno'. Não podemos nos descrever a nós mesmos sem descrever e entender o que é e o que faz o entorno do qual formamos parte. No entanto, educaram-nos para nos entendermos e 'vivermos' como se fôssemos entes isolados de consciência e de açāo, postos em um mundo que não é o nosso, que nos é estranho, que é diferente do que somos e fazemos e, por esta razāo, podemos dominar e explorar. Ver o mundo a partir de um pretenso centro, supōe entender a realidade material como algo inerte, passivo, algo a que se necessita dar forma desde uma inteligência alheia a ela. Ver o mundo a partir da periferia, implica entendermo-nos como conjuntos de relaçōes que nos atam, tanto interna como externamente, a tudo, e a todos os demais. A solidāo do centro supōe a dominaçāo e a violência. A pluralidade das periferias supōe o diálogo, a convivência".

${ }^{10}$ Flores (2002, p. 11) refere que, dentro dessa lógica, "o país que recepciona manda; o imigrante, diferente/desigual, serve: estamos ante a lei de oferta e demanda aplicada, neste caso, à tragédia pessoal de milhōes de pessoas que fogem do empobrecimento de seus Países, em razão da rapina indiscriminada do capitalismo globalizado".
} 
em outros espaços do globo que não a Europa. (MAGALHĀES, 2012, p. 26)

Tal dominação ideológica, por conseguinte, efetuada pelos europeus criou a ideia de que a Europa é um padrão que todos devem seguir, porquanto se trata de uma civilização mais avançada que as demais e, portanto, o destino natural a ser seguido por todos. É, por tal motivo, que essa naturalização histórica dispõe que as compreensōes e visōes de mundo das outras civilizações distintas da ocidental são não só inferiores, como menos evoluídas.

Tem-se na figura da globalização, a qual serve de sustento e fomento do capitalismo e que tem por pretensão a limitação de fronteiras econômicas, um fenômeno que favorece a manutenção não só da desigualdade, como também da exclusão social nos dias de hoje. É, nesse sentido, que Santos (2008, p. 393), ao compreender a globalização associada à universalidade, reconhece que os grupos sociais hegemônicos sujeitam aos seus valores e regras e dominam as comunidades menores, ocasionando atrocidades como, por exemplo, conflitos étnicos, além de, e principalmente, negar a existência do Sul e trazer estereótipos preconceituosos como a noção de que o Norte é desenvolvido, o Sul é subdesenvolvido; o Norte é rico, o Sul é pobre, de forma que a globalização acaba por mascarar as realidades (SANTOS, 2008, p. 395) e por assegurar o processo de dominação.

Essa mesma lógica foi utilizada pelo colonialismo, o qual concebeu uma relação de exploração da metrópole europeia e suas colônias e de oposição. Assim, pode-se afirmar que a globalização, em verdade, sustenta o mesmo discurso e o mesmo modo de se operar do colonialismo, abarcando as ideias de superioridade e inferioridade de identidade, sob a pretensa de se universalizar (e, portanto, uniformizar) as culturas diversas da ocidental; mantendo, portanto, a noção de dominação imperialista.

É, nessa mesma perspectiva, que Magalhães (2012, p. 23) assevera que a modernidade, arqui- tetada a partir do final do século XV, demanda padronizar e igualar os menos diferentes, no caso os homens europeus ocidentais, e excluir os mais diferentes, as mulheres, os índios, os negros, os pobres, dentro do processo de constituição da identidade nacional, de maneira que esta rejeição, rebaixamento ou encobrimento do "outro" está na base de várias formas de violência típicas do Estado Moderno (seja ele absolutista, liberal, social ou democrático).

Tal universalismo dos direitos humanos, portanto, acaba por criar um processo de invisibilidade e opressão ao grupo diferente, fortalecido pela concepção de raça, bem como pelo desempenho do poder a partir de uma matriz colonial. Esse processo de dominação produz a imagem do colonizado subalterno como sendo sujeito irracional, ou seja, não detentor de liberdade e autonomia. Destarte, a acepção do discurso dos direitos humanos, embora marcada por traços universais, é fruto de práticas colonizadoras, como sustentam Bragato, Romaguera e Teixeira (2014, p. 19), no sentido de que "a construção colonial na modernidade definiu universalmente o sujeito de direitos, a bem da verdade, o humano, atrelado aos padrōes do eurocentrismo".

Por fim, observa-se que a tradição dos direitos humanos, a começar de sua criação clássica da natureza contra a lei até as lutas contemporâneas por libertação política e dignidade da pessoa humana frente à legislação estatal, sempre revelou o cenário do "ainda não", o panorama do futuro, como expōe Douzinas (2009, p. 157), de maneira que os direitos humanos acabaram também por se transformar no "grito do oprimido, do explorado".

É, nessa perspectiva, que Douzinas (2009, p. 253) dispōe que

Os direitos humanos representam o elemento utópico por trás dos direitos legais. Os direitos constituem o alicerce de um sistema jurídico liberal. Os direitos humanos constituem sua reivindicação de justiça e, como tal, são impossíveis e 
prospectivos. Os direitos humanos são parasitas no corpo dos direitos, que julgam seu hospedeiro. Existe uma poética nos direitos humanos que desafia o racionalismo da lei: quando uma criança em chamas foge de uma cena atroz no Vietnā, quando um jovem se coloca na frente de um tanque em Beijing, quando um corpo esquelético e de olhos apáticos encara a câmera por trás da cerca de um campo de concentração na Bósnia, um sentimento trágico irrompe e me coloca, como espectador, cara a cara com a minha responsabilidade que não deriva de códigos, nem de convençōes ou regras, mas de um sentimento de culpa pessoal pelo sofrimento no mundo, de uma obrigação de salvar a humanidade aos olhos da vítima.

Assim, observou-se que a construção do discurso dos direitos humanos, para além de deter um caráter hegemônico, é calcada nas insurgências da burguesia da modernidade ocidental, tendo por proteção a figura do homem branco europeu. É por tal razão que se sustenta que os direitos humanos são estimados como resultados das lutas com valores e necessidades de uma cultura, a ocidental, de modo que tais direitos ou não têm a ver com a narrativa histórica, ou com a visão de mundo dos povos tidos como não ocidentais.

Como visto, tal fundamentação acaba por permitir um cenário de exclusão e estranhamento daqueles que não só não fazem parte da cultura ocidental, como também não representam a imagem ${ }^{11}$ do homem branco burguês. Muzaffar (1999, p. 26), nesse tópico, relembra que "enquanto a Europa construía o edifício dos direitos individuais dentro de suas próprias fronteiras, destruía a pessoa humana em outras terras. Enquanto os direitos humanos expandiam-se entre os povos brancos, o império europeu infligiu horríveis sofrimentos sobre os habitantes de cor do Planeta".

O cenário no qual se encontra, por exemplo, o contexto latino-americano foi elaborado a partir da dominação dos povos, no âmbito interno, e na submissão à metrópole, no campo externo. É essa lógica da colonização que explora e exclui, desde os primórdios, alguns grupos étnicos não representantes do grupo dominante. Isso gerou e, ainda ocasiona, uma série de desigualdades sociais, de forma que tal situação acaba por legitimar a violência contra as minorias e a marginalização desses.

Desta feita, a aderência dos modelos de vida (seja político, como econômico, cultural e social) de cunho eurocêntrico e imperialista norte-americano ao sistema local tem permitido que gere problemas estruturais de dominação econômica $e$ de exclusão social, de maneira que se inviabilize um sistema jurídico que prime por um viés pluricultural, instando que se ultrapasse a concepção individualista, monocultural e positivista dos direitos humanos, a fim de que, com base numa igual dignidade das culturas, se possa desenvolver uma definição e interpretação intercultural dos direitos humanos (FAJARDO, 2004, p. 198).

A interculturalidade, como aponta Walsh (2010, p. 5), vai além do reconhecimento da diversidade e da inclusão, porquanto manifesta-se e coloca em jogo a diferença colonial, como também a colonialidade do poder incessante. Assim, de acordo com esse entendimento, a interculturalidade representa um projeto de caráter e orientação decolonial, de cunho político, social, ético e epistêmico, tendo em vista que pretende transformar e construir condiçōes de estar, ser pensar, conhecer, aprender (WALSH, 2010, p. 6) distintas daquela pré estabelecida por conta do universalismo europeu; buscando, por conseguinte, a troca de saberes nas relaçōes sócias, bem como nas estruturas de poder, as quais mantém o cenário de subalternidade e discriminação dos "outros" a partir da racialização iniciada no período colonial e permanecida até os dias de hoje.

\footnotetext{
${ }^{11}$ Por tal motivo que ainda se examina na sociedade, inclusive (e principalmente) ocidental, a discriminaçāo, o preconceito e a criminalização contra e do negro, da mulher, do pobre, vez que o discurso, para além de criar e permitir, potencializa os estereótipos de inferioridade e dominação.
} 
Tendo em vista que se trata de um processo não só dinâmico, como também permanente de trocas/intercâmbios entre as culturais de um determinado espaço geográfico, a interculturalidade pugna por uma tarefa social e política, ampliada ao campo também jurídico, que "interpela o conjunto da sociedade, que parte de práticas e açōes sociais concretas e conscientes e tenta criar modos de responsabilidade e solidariedade" (WALSH, 2001, p. 10). Assim, pretende-se a renovação do pensamento crítico, advindo a partir da visão do "outro", impulsionado exatamente pela vivência da colonialidade, desfazendo-se das heranças eurocêntricas.

Dessa feita, a interculturalidade tem por pretensão a resistência frente a não só o colonialismo sofrido, principalmente no que tange à realidade latino americana, mas também a toda estrutura decorrente da colonialidade (WALSH, 2007); tratando-se da interculturalidade uma prática contra hegemônica que visa à reinvenção ${ }^{12}$ dos direitos humanos a partir da periferia mundial, do conhecimento e dos saberes produzidos pelo Sul global com o fim de encerrar toda a dicotomia que a modernidade/colonialidade trouxe.

\section{Considerações finais}

A partir deste artigo, buscou-se, alicerçado na crítica ao discurso dos direitos humanos, de caráter eurocêntrico, universal, ocidental, branco e patriarcal, o qual é a base de diversas instituiçōes estatais e do sistema jurídico atual, repensar o direito a fim de que ele se firme como pluralista, intercultural, não reprodutor de desigualdades e opressōes.

Tendo em vista que os direitos humanos foram concebidos, de forma consolidada, a partir das revoluçōes burguesas, como sendo universais e assegurados a todos pelo simples fato de serem humanos (reforçando a concepção jusnaturalista) e que se vislumbram diversas transgressōes a essa universalidade desde suas positivaçōes e formulaçōes com início nas declaraçōes da modernidade até os dias de hoje, observou-se que o fundamento eurocêntrico dos direitos humanos é excludente e garantidor de uma única identidade, a qual é lançada como uma razão universal, de forma que essa racionalidade foi sustentada numa noção colonial em que se restringia a humanidade dos nativos nos países colonizados, como forma de exercer o poder e a dominação sobre os povos.

Foi, por conta desse processo, que diversas culturas distintas da europeia, povos que detivessem identidades diferentes da dominante, foram sistematicamente inferiorizados, tiveram seus valores e modos de vida negados, sua humanidade questionada e infantilizada, resultando numa conjuntura de opressão e marginalização do "Outro", fazendo com que a proteção dos direitos humanos fosse assegurada na metrópole europeia, enquanto que esse mesmo Estado era transgressor desses mesmos direitos que garantia, porém nas colônias latino americanas, africanas e asiáticas.

Assim, pretendeu-se demonstrar a necessidade de se criticar toda a construção do discurso dos direitos humanos, a partir da decolonialidade, a fim de que os povos do Sul global possam buscar espaço por meio da legitimação de sua produção do conhecimento em matéria de direitos humanos, tendo em vista que essa concepção eurocêntrica abarca todo um processo de objeção às atrocidades perpetradas ao imperialismo do Estado, como bem sustenta Barreto (2013), razão pela qual "é preciso romper com a modernidade e desocultar a diversidade, criando uma sociedade não hegemônica, sem nós ou eles; sem civilizados ou incivilizados; sem proprietários e empregados" (MAGALHĀES, 2013, p. 126).

\footnotetext{
${ }_{12}$ Flores (2002, p. 28) defende que "reivindicar a interculturalidade não se limita, por outro lado, ao necessário reconhecimento do outro. É preciso, também, transferir poder, "empoderar" aos excluídos dos processos de construção de hegemonia. E, assim, trabalhar para a criação de mediaçōes políticas, institucionais e jurídicas que garantam dito reconhecimento e dita transferência de poder".
} 
A interculturalidade vem como uma possível saída igualitária como resistência ao caráter opressor e desigual dos direitos humanos, porquanto se abre espaço para que os grupos marginalizados e as minorias excluídas e silenciadas possam transformar as estruturas e reinventar as dinâmicas sociais.

\section{Referências}

BALDI, César Augusto. Da Diversidade de Culturas à Cultura da Diversidade: Desafios dos Direitos Humanos. In: ROSILLO, Alejandro; et al. Teoria Crítica dos Direitos Humanos no século XXI. Porto Alegre: EDIPUCRS, 2008.

BARRETO, Jose-Manuel. Imperialism and Decolonization as scenarios of human rights history. In: BARRETO, Jose-Manuel (Org.). Human Rights from a Third World Perspective. Reino Unido: Cambridge Scholars Publishing, 2013.

BIELEFELDT, Heiner. A filosofia dos direitos humanos. São Leopoldo: Unisinos, 2000.

BOBBIO, Norberto. A era dos direitos. Tradução: Carlos Neslon Coutinho. Rio de Janeiro: Elsevier, 2004.

BRAGATO, Fernanda Frizzo. Direitos Territoriais indígenas e descolonialidade. In: STRECK, Lenio Luiz; ROCHA, Leonel Severo; ENGELMANN, Wilson (Org.). Constituição, Sistemas Sociais e Hermeneutica: anuário do programa de Pós Graduação em Direito da UNISINOS. Porto Alegre: Livraria do Advogado, 2014.

BRAGATO, Fernanda Frizzo. Uma crítica descolonial ao discurso eurocêntrico dos direitos humanos. In: LOPES, Ana Maria D'Ávila; MAUÉS, Antônio Moreira (Org.). A Eficácia Nacional e Internacional dos Direitos Humanos. Rio de Janeiro: Lumen Juris, 2013.

BRAGATO, Fernanda Frizzo. Pessoa Humana e Direitos Humanos na Constituição Brasileira de 1988 a partir da perspectiva pós-colonial. 2009. 267 f. Tese (Doutorado) - Curso de Direito, Unisinos, São Leopoldo, 2009.

BRAGATO, Fernanda Frizzo; ROMAGUERA, Daniel Carneiro Leão; TEIXEIRA, João Paulo Allain. Por uma Crítica Descolonial da Ideologia Humanista dos Direitos Humanos. Derecho y Cambio Social, ISSN 2224-4131, ano 11, n. 38, 2014.

BRAGATO, Fernanda. Para além do discurso eurocêntrico dos direitos humanos: contribuiçōes da descolonialidade. Revista Novos Estudos Jurídicos. Eletrônica. vol. 19, n. 1. jan-abr, 2014.
CASTILHO, Natalia Martinuzzi. Pensamento Descolonial e Teoria Crítica dos Direitos Humanos na América Latina: um diálogo a partir da obra de Joaquín Herrera Flores. 2013. 194 f. Dissertação (Mestrado) - Curso de Direito, Unisinos, São Leopoldo, 2013.

COMPARATO, Fábio Konder. A afirmação histórica dos direitos humanos. 3. Ed. São Paulo: Editora Saraiva, 2004.

DONNELLY, Jack. Universal Human Rights in Theory and Practice. 3rd ed. New York: Cornell University, 2013.

DOUZINAS, Costas. 0 Fim dos Direitos Humanos. Tradução: Luzia Araújo. São Leopoldo: Editora Unisinos, 2009.

FAJARDO, Raquel Yrigoyen. Vislumbrando um Horizonte Pluralista: Rupturas y Retos Epistemológicos y Políticos. In: LUCIC, Milka Castro. Los Desafios de la Interculturalidad: Identidad, Política y Derecho. Santiago: Universidad de Chile, 2004.

FLORES, Joaquín Herrera. Direitos Humanos, Interculturalidade e Racionalidade e]de Resistência. Sequencia, Revista do Curso de Pós Graduação em Direito da UFSC. v. 23, n. 44. Florianópolis: UFSC, 2002.

LAFER, Celso. A Reconstrução dos Direitos Humanos: um diálogo com o pensamento de Hannah Arendt. São Paulo: Editora Schwarcz, 2001.

MAGALHĀES, José Luiz Quadros de. 0 Estado Plurinacional e o Direito Internacional Moderno. Curitiba: Juruá Editora, 2012.

MAGALHĀES, José Luiz Quadros de. 0 novo constitucionalismo democrático na América Latina e a superação da modernidade europeia. 2013. Disponível em: «http:// faa.edu.br/revistas/docs/RID/2013/RID_2013_08.pdf.

MUZZAFAR, Chandra. From human rights to human dignity. In: NESS, Peter Van. Debating human rights - critical essays from the United States and Asia. London: Routledge, 1999.

PIOVESAN, Flávia. Direitos Humanos e o Direito Constitucional Internacional. São Paulo: Editora Saraiva, 2010.

QUIJANO, Aníbal. Colonialidade do Poder, eurocentrismo e América Latina. In: LANDER, Edgardo (Org.). A colonialidade do saber: eurocentrismo e ciências sociais. Buenos aires: CLACSO, 2005.

RAMOS, André de Carvalho. Curso de Direitos Humanos. 3. Ed. rev. atual. ampl. São Paulo: Editora Saraiva, 2016.

SAID, Edward. Cultura e imperialismo. São Paulo: Companhia das Letras, 1995.

SANTOS, Boaventura de Souza. A gramática do tempo: para uma nova cultura política. 3. ed. São Paulo: Cortez, 2008. 
SANTOS, Boaventura de Souza. Para uma concepção multicultural dos Direitos Humanos. In: SARMENTO, Daniel; IKAWA, Daniela; PIOVESAN, Flávia (Coord.). Igualdade, diferença e direitos humanos. Rio de Janeiro: Lumen Juris, 2010.

WALLERSTEIN, Immanuel. 0 universalismo europeu: a retórica do poder. São Paulo: Boitempo, 2007.

WALSH, Catherine. Interculturalidad crítica y pluralismo jurídico. 2010. Disponível em: ‘file:///E:/Ctherine_Walsh_ Interculturalidade_e_Pluralismo_Jurídico.pdfi.
WALSH, Catherine. La educación intercultural en la educación. Peru: Ministerio de Educación, 2001.

WOLKMER, Antonio Carlos. Introdução ao Pensamento Jurídico Crítico. 9 ed. São Paulo: Saraiva. 2015.

WOLKMER, Antonio Carlos. Pluralismo Jurídico e Direitos Humanos: Dimensões Emancipadoras. In: ROSILLO, Alejandro; et al. Teoria Crítica dos Direitos Humanos no século XXI. Porto Alegre: EDIPUCRS, 2008.

\section{Michelle Alves Monteiro}

Especialista em Direito Público (ESMAFE/RS), Graduada em Direito (PUCRS). Integrante do SEMEAR (Núcleo de Assessoria Jurídica a povos e comunidades indígenas e Quilombolas), vinculado ao SAJU/UFRGS.

\section{Tatiana Cardoso Squeff}

Doutora em Direito Internacional pela UFRGS (2018), com período sanduíche junto a University of Ottawa. Mestre em Direito Público pela Unisinos/Univeristy of Toronto, com fomento CAPES/DFAIT (2012). Pós-graduada em Relaçōes Internacionais pela UFRGS/PPGEEI (2015), em Direito Internacional pela UFRGS/PPGD (2009) e em Língua Inglesa pela Unilasalle (2008). Professora Universitária de Direito Internacional e Relaçōes Internacionais, atualmente ministrando aulas na UNIFIN/RS. 